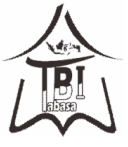

\title{
PENDIDIKAN KARAKTER DALAM KUMPULAN CERPEN TRANSIT KARYA SENO GUMIRA AJIDARMA DAN IMPLIKASINYA TERHADAP PEMBELAJARAN BAHASA INDONESIA DI SMA
}

\author{
Innes Amilia Sari ${ }^{1}$, Agus Sulaeman ${ }^{2}$, Haerudin $^{3}$ \\ Universitas Muhammadiyah Tangerang \\ Pos-el: innesamilia50@gmail.com ${ }^{1}$,sultanwahyu13@gmail.com², \\ haerromli@gmail.com ${ }^{3}$
}

Diserahkan: 15 Agustus 2020, Direvisi: 30 Oktober 2020, Diterima: 11 Februari 2021

\section{Abstract}

This research discusses the Character Education of the Transit Short Story Collection by Seno Gumira Ajidarma and its implications for learning Indonesian in high school. The purpose of this study is to describe the value of character education contained in the collection of short story Transit by Seno Gumira Ajidarma in the form of values of religious, nationalist, integrity, self-reliance, mutual cooperation and their implications for learning Indonesian in high school. In this study, researchers used a qualitative approach with content analysis methods. The data used in this study are words, sentences or expressions in the short story entitled: 1) Jakarta City Tour, 2) Sepatu Kulit Ular, 3) Segawon, 4) Transit, 5) Gubrak, 6) Istana Tembok Bolong, 7) Setan Becak, 8) GoKill, 9) Budak Cinta, 10) Setan Banteng which shows the value of character education. Data collection techniques in this research are literature and note- 
taking techniques. The results showed that the researchers found thirty-one values. The collection of short stories Transit can be implied and can be used as teaching materials for Indonesian language learning in high school class XI semester 1 with the 2013 curriculum at KD 3.8 .

Keywords: Short Story, Character Education

\begin{abstract}
Abstrak
Penelitian ini membahas tentang pendidikan karakter dalam kumpulan cerpen Transit karya Seno Gumira Ajidarma dan implikasinya dengan pembelajaran bahasa Indonesia di SMA. Tujuan dalam penelitian ini adalah untuk mendeskripsikan nilai pendidikan karakter yang terdapat dalam kumpulan cerpen Transit karya Seno Gumira Ajidarma berupa nilai karakter religius, nasionalis, integritas, mandiri, gotong royong dan relevansinya dengan pembelajaran bahasa Indonesia di SMA. Dalam penelitian ini, peneliti menggunakan pendekatan kualitatif dengan metode analisis isi. Data yang digunakan dalam penelitian ini adalah kata-kata, kalimat atau ungkapan pada cerpen yang berjudul: 1) Jakarta City Tour, 2) Sepatu Kulit Ular, 3) Segawon, 4) Transit, 5) Gubrak!, 6) Istana Tembok Bolong, 7) Setan Becak, 8) GoKill, 9) Budak Cinta, dan 10) Setan Banteng yang menunjukkan nilai pendidikan karakter. Teknik pengumpulan data dalam penelitian ini adalah teknik kepustakaan dan catat. Hasil penelitian menunjukkan bahwa peneliti menemukan tiga puluh satu nilai pendidikan karakter. Kumpulan cerpen Transit dapat diimplikasikan sebagai bahan ajar bahasa Indonesia di SMA kelas XI semester 1 pada KD 3.8 .
\end{abstract}

Kata Kunci: Cerpen, Pendidikan Karakter

\title{
PENDAHULUAN
}

Karya sastra merupakan ciptaan manusia yang di dalamnya tertuang ide, gagasan, pemikiran dan pemahaman yang menggambarkan berbagai macam masalah kehidupan lalu 
diekspresikan pengarang menggunakan bahasa yang kreatif dan imajinatif. Karya sastra yang baik adalah karya sastra yang mampu memberikan kesenangan dan memberikan pengaruh kepada pembaca, selain dapat menjadi hiburan bagi pembaca karya sastra juga menjadi media pengarang untuk memberikan serta mendidik para pembaca dengan nilai-nilai yang ada dalam ceritanya. Setelah membaca karya sastra, pembaca diharapkan mampu membedakan nilai positif dan negatif sehingga dapat hal yang baik dapat diaplikasikan dalam kehidupan bermasyarakat.

Karya sastra yang tidak asing dalam kehidupan sehari-hari yaitu cerita pendek. Cerita pendek adalah karya sastra yang isinya cenderung lebih singkat dan langsung pada tujuannya sehingga dapat selesai dibaca dalam satu kali pembacaan, berbeda dengan karya sastra lain seperti novel. Cerita pendek banyak mengandung nilai-nilai kehidupan berdasarkan kreasi dan imajinasi pengarang yang digambarkan menggunakan bahasa yang dramatik. Cerpen diciptakan bukan hanya menjadi hiburan bagi pembacanya, tetapi dapat dijadikan sebagai motivasi atau acuan untuk berperilaku baik terhadap lingkungan sekitarnya, karena di dalamnya terdapat nilai kehidupan seperti nilai moral, agama, dan nilai pendidikan karakter. Cerita pendek sebagai salah satu bentuk karya sastra tertulis yang menarik dan menjadi penting untuk dikaji. Terutama dalam hal memahami, menganalisis dan menilai sebuah karya sastra dengan mempertimbangkan segi-segi kemasyarakatan (sosial), seperti halnya pengarang ingin menyampaikan pesannya lewat karya sastra kepada masyarakat atau pembacanya. Oleh karena itu, isi karya sastra akan sangat bergantung kepada pengarangnya, baik dari latar belakang pendidikan, pengalaman, pengetahuan ataupun keyakinannya (Sutri, 2020:17).

Akhir-akhir ini, peran lembaga pendidikan banyak disorot oleh masyarakat. Terjadinya kasus tawuran antar pelajar, perilaku asusila, penyalahgunaan narkoba, kekerasan siswa terhadap orang tua dan guru, dan berbagai kasus lain yang melibatkan siswa dianggap sebagai indikator lemahnya peran pendidikan dalam membentuk karakter siswa (Yulianto, 2020:110). Perkembangan zaman sangat 
mempengaruhi terbentuknya karakter seseorang karena manusia bisa menerima berbagai masukan melalui pergaulan sehari-hari, serta dapat meniru semua perilaku yang dilihat dan didengar.

Pendidikan karakter adalah pendidikan budi perkerti plus, yaitu melibatkan aspek pengetahuan (cognitive), perasaan (feeling), dan tindakan (action) (Salahudin dan Alkrienciehie, 2017:45). Pendidikan karakter bukan hanya mengajarkan teori tentang nilainilai moral kepada perserta didik, tetapi harus disertai dengan tindakan dan perasaan, karena hal itu sejalan dengan tindakan yang akan dilakukan perserta didik ketika berada di lingkungan sekitarnya. Perkembangan zaman sangat mempengaruhi terbentuknya karakter seseorang karena manusia bisa menerima berbagai masukan melalui pergaulan sehari-hari, serta dapat meniru semua perilaku yang dilihat dan didengar.

Sehubungan dengan gencarnya pemerintah menanamkan pendidikan karakter kepada perserta didik sesuai dengan Peraturan Presiden No. 87 tahun 2017 tentang Penguatan Pedidikan Karakter Jadi Pintu Masuk Pembenahan Pendidikan Nasional. Kementerian Pendidikan dan Kebudayaan mengimplementasikan penguatan karakter melalui gerakan Penguatan Pendidikan Karakter (PPK), pembelajaran sastra dianggap penting dan dapat membantu untuk membentuk watak perserta didik. Pembelajaran bahasa Indonesia mencakup empat keterampilan berbahasa yakni menyimak, berbicara, membaca, serta menulis. Pembelajaran bahasa Indonesia berkaca dari kurikulum 2013 dirancang menjadi pembelajaran berbasis teks. Sitem ini diharapkan mampu menjadikan siswa memiliki kompetensi yang komprehensif pada empat keterampilan tersebut (Widiatmoko, 2020:70)

Dilihat dari menyimpangnya pergaulan perserta didik di sekitar yang membuat pendidik atau pemerintah cemas mengenai masa depan bangsa yang nantinya akan dipimpin oleh generasi penerus. Pendidikan karakter dapat ditanamkan dalam diri perserta didik sedini mungkin melalui pembelajaran sastra di sekolah yang dapat menjadi alternatif untuk membentuk karakter dalam diri 
seseorang. Nilai pendidikan karakter yang positif dapat membantu mengembangkan karakter pembaca khususnya perserta didik. Oleh karena itu, penelitian ini membahas tentang bagaimana nilai pendidikan karakter yang terkandung dalam kumpulan cerpen Transit karya Seno Gumira Ajidarma berupa nilai karakter religius, nasionalis, integritas, mandiri, gotong royong dan implikasinya dalam pembelajaran bahasa Indonesia di SMA.

Adapun tujuan penelitian ini untuk mendeskripsikan dan mengetahui nilai pendidikan karakter yang terkandung dalam kumpulan cerpen Transit karya Seno Gumira Ajidarma berupa nilai karakter religius, nasionalis, integritas, mandiri, gotong royong dan implikasinya dengan pembelajaran bahasa Indonesia di SMA.

\section{KAJIAN LITERATUR}

Sastra di Indonesia berkembang dengan pesat sesuai dengan kemajuan zaman, karya sastra yang mendukung kemajuan sastra di Indonesia adalah cerita pendek. Cerpen adalah karya sastra yang di dalamnya terkandung nilai-nilai kehidupan yang dituangkan oleh pengarang menggunakan bahasa sehari-hari dengan maksud memudahkan pembaca dalam menangkap dan menyimpulkan cerita. Sesuai dengan perkembangan sastra di Indonesia, pengarang kini bebas menuangkan gagasan dalam karyanya tanpa dibatasi oleh hal-hal tertentu.

Cerpen merupakan suatu cerita fiksi berbentuk prosa yang singkat dan pendek yang unsur ceritanya terpusat pada suatu peristiwa pokok. Jumlah dan pengembangan pelaku terbatas dan keseluruhan cerita memberikan kesan tunggal (Wicaksono, 2014:57). Cerpen cenderung padat dan terfokus pada satu tema sehingga pembaca dapat mengikuti rangkaian cerita sesuai dengan alur. Jumlah kata dalam cerpen yang terbatas mengharuskan pengarang membuat cerpen secara rinci sehingga dapat memberikan kesan tunggal bahkan tokoh dan latarnya pun sedikit. Dengan begitu, pembaca dapat dengan mudah memahami isi cerita meskipun hanya dengan sekali membaca. 
Cerita pendek diciptakan bertujuan untuk menyampaikan maksud tertentu kepada pembaca, salah satunya menyampaikan nilai-nilai yang baik yang dapat dijadikan teladan sehingga dapat membentuk pendidikan karakter perserta didik ketika membaca suatu karya sastra. Nilai yang disampaikan pengarang yang terkandung dalam karya sastra diharapkan mampu tersampaikan kepada pembaca dan dapat dipraktikkan dengan baik ketika hidup bermasyarakat. Pendidikan karakter dalam hal ini dapat dikatakan sebagai suatu sistem penanaman nilai-nilai karakter atau pengembangan etika melalui olah pikir, olah hati, olahraga, olah rasa, dan karsa yang meliputi komponen pengetahuan, kesadaran, dan tindakan untuk melaksanakan nilai-nilai tersebut dalam kehidupan sehari-hari (Youpika \& Zuchdi, 2016:50). Dalam menanamkan pendidikan karakter kepada perserta didik bukan hanya melalui perilakunya saja tetapi mencakup keseluruhan dalam diri peserta didik, sehingga dapat diterima dengan baik oleh dirinya dan masyarakat disekitarnya.

Di dalam Grand Design Pendidikan Karakter dalam diungkapkan nilai-nilai yang terutama akan dikembangkan dalam budaya satuan pendidikan formal dan nonformal terbagi atas tujuh, meliputi: 1) Jujur, 2) tanggung jawab, 3) cerdas, 4) sehat dan bersih, 5) peduli, 6) kreatif, 7) gotong-royong (Samani \& Hariyanto, 2017:51). Sedangkan Kementerian Pendidikan dan Kebudayaan mengimplementasikan penguatan karakter melalui gerakan Penguatan Pendidikan Karakter (PPK). Ada lima nilai karakter utama yang menjadi prioritas pengembangan gerakan PPK, yakni: 1) Nilai religius, mencerminkan keberimanan terhadap Tuhan Yang Maha Esa yang diwujudkan dalam perilaku melaksanakan ajaran agama dan kepercayaan yang dianut, menghargai perbedaan agama, menjunjung tinggi sikap toleran terhadap hidup rukun dan damai dengan pemeluk agama lain, (2) Nilai nasionalis, merupakan cara berpikir, bersikap, dan berbuat yang menunjukkan kesetiaan, kepedulian, dan penghargaan yang tinggi terhadap bahasa, lingkungan fisik, sosial budaya, ekonomi, dan politik bangsa, mementingkan kepentingan bangsa dan negara di atas kepentingan 
diri dan kelompoknya, (3) Nilai integritas, nilai yang mendasari perilaku yang didasarkan pada upaya menjadi dirinya sebagai orang yang selalu dapat dipercaya dalam perkataan, tindakan, dan pekerjaan, memiliki komitmen dan kesetiaan pada nilai-nilai kemanusiaan dan moral, (4) Nilai mandiri, sikap dan perilaku tidak bergantung pada orang lain dan mempergunakan segala tenaga, pikiran, waktu, untuk merealisasikan harapan, mimpi, dan cita-cita. Siswa yang mandiri memiliki etos kerja yang baik, tanggung, berdaya juang professional, kreatif, keberanian, dan menjadi pembelajar sepanjang hayat, 5) Nilai gotong-royong, mencerminkan tindakan menghargai semangat kerja sama dan bahu membahu menyelesaikan persoalan bersama, menjalin komunikasi dan persahabatan, memberi bantuan/ pertolongan pada orang-orang yang membutuhkan. (Kementrian Pendidikan dan Kebudayaan, 2017).

Pembelajaran tidak pernah lepas dari kehidupan manusia, sebelum manusia memahami sesuatu pasti memerlukan proses yang dinamakan pembelajaran. Pembelajaran tidak harus selalu dilaksanakan di sekolah, tetapi dapat secara formal dan nonformal melalui peristiwa yang terjadi di kehidupan sehari-hari dalam bermasyarakat. Pembelajaran yang dapat dipelajari adalah pembelajaran sastra. Pembelajaran sastra yang dilaksanakan di sekolah bukan tanpa tujuan. Peserta didik diharapkan mampu memahami dan mempelajari makna yang diajarkan oleh pendidik maupun yang terdapat dalam karya sastra.

Model pembelajaran merupakan strategi atau langkahlangkah pembelajaran yang digunakan guru untuk meningkatkan motivasi belajar, sikap belajar di kalangan perserta didik, mampu berpikir kritis, memiliki keterampilan sosial, dan pencapaian hasil pembelajaran yang maksimal (Sulaeman \& Ariyana, 2018:17). Model pembelajaran yang kreatif dan inovatif sangat berpengaruh untuk membentuk motivasi perserta didik dalam mengikuti kegiatan pembelajaran sehingga di akhir nanti mendapatkan hasil pembelajaran yang baik. 


\section{METODE PENELITIAN}

Penelitian ini menggunakan pendekatan kualitatif dengan metode analisis isi. Metode analisis isi yang diutamakan adalah isi dari suatu komunikasi dalam penelitian sastra. Bentuk analisis isi berkaitan dengan bentuk verbal bahasa dan nonverbal (Hudhana, 2018:101). Kaitan dengan penelitian tersebut, berikut langkah yang dilakukan oleh peneliti, yaitu: (1) membaca keseluruhan isi kumpulan cerpen Transit karya Seno Gumira Ajidarma, (2) mengamati keseluruhan isi kumpulan cerpen Transit karya Seno Gumira Ajidarma, (3) menandai dan mencatat kata yang mengandung nilai pendidikan karakter, (4) mengelompokkan nilai pendidikan karakter yang ditemukan ke dalam tabel analisis berupa: nilai religius, nilai nasionalis, nilai integritas, nilai mandiri, dan nilai gotong-royong, (5) menganalisis nilai pendidikan karakter dalam kumpulan cerpen Transit karya Seno Gumira Ajidarma, (6) menyimpulkan hasil analisis.

Teknik pengumpulan data dalam penelitian ini adalah teknik kepustakaan dan catat. Dalam hal ini kajian terhadap teks kumpulan cerpen Transit karya Seno Gumira Ajidarma sebagai data utama atau data primer. Peneliti menganalisis data dengan langkah sebagai berikut: (1) membaca secara kritis sumber data dalam kumpulan cerpen Transit karya Seno Gumira Ajidarma. Membaca secara teliti untuk memahami makna yang terdapat di dalam sumber data, (2) membaca secara berkesinambungan dan berulang-ulang sumber data dalam kumpulan cerpen Transit karya Seno Gumira Ajidarma, (3) mengumpulkan dan mengklasifikasikan nilai pendidikan karakter yang terdapat dalam kumpulan cerpen Transit karya Seno Gumira Ajidarma, (4) penyajian data dalam tabel berupa hasil klasifikasi data secara kategorial, (5) memaparkan hasil penelitian secara menyeluruh serta membuat kesimpulan.

\section{HASIL PENELITIAN DAN PEMBAHASAN}

Berikut nilai pendidikan karakter yang terdapat dalam kumpulan cerpen Transit karya Seno Gumira Ajidarma. 


\section{Nilai Religius}

Cerpen yang berjudul "Jakarta City Tour" memiliki nilai karakter religius yang ditunjukkan pada kutipan berikut.

Tidak ada yang bisa memastikan, arwah-arwah mereka diterima di sisi Tuhan atau tidak. (h.9)

Kutipan tersebut menunjukkan bahwa pengarang mempercayai bahwa setiap mahluk yang meninggal dunia pasti kembali kepada penciptanya dan digambarkan dalam cerpen tersebut, tetapi dalam cerpen ini pengarang menggambarkannya dengan penuh keragu-raguan apakah arwah-arwah para turis tersebut diterima di sisi Tuhan atau tidak.

Cerpen lain yang mengandung nilai Pendidikan karakter religius terdapat pada cerpen berjudul "Pulang Berpulang" yang ditunjukkan pada kutipan berikut.

"Setiap tahun larangannya semakin keras, tetapi kami tetap datang jua dengan sepeda motor kami masing-masing, berselancar di atas gelombang samudera sepeda motor, dan memang dalam dua tahun berturut-turut, kakakku kedua dan ketiga menyusul kakak pertama, tewas sebagai pemudik bersepeda motor." Apakah itu harus berarti aku akan dan pasti mati jika melakukan pemudikan dengan mengendarai sepedamotor? Jika tidak pasti, mengapa kami harus bersikap seolah-olah hal itu pasti? Jika pasti, kematian macam apapun, bukankah mustahil dihindari? (h.67)

Kutipan tersebut menggambarkan bahwa tokoh "Sukab" mempercayai kematian itu sesuatu tidak bisa dihindari. Hal tersebut menggambarkan bahwa Sukab mempercayai bahwa kematian sudah digariskan oleh Tuhan dan tidak ada manusia yang mengetahui kapan ia akan mati meskipun "Sukab" akhirnya memutuskan tetap melakukan mudik dengan mengendarai sepeda motor.

Selanjutnya yaitu cerpen yang berjudul "GoKill". Berikut ini adalah nilai Pendidikan karakter religius dalam cerpen "GoKill" ditunjukkan dalam kutipan di bawah ini:

Sampai sekarang sudah 35 tahun kujalani perkerjaanku dengan cara yang disebut-sebut sebagai profesional. Kukira tiada 
manusia maupun lembaga yang dibentuk manusia di muka bumi ini akan bisa menangkapku. Hanya Malaikat Maut, atas perkenan Tuhan yang Maha Esa bisa membawa dan mencabut nyawaku, tapi itu bukanlah masalahku. (h.108)

Kutipan di atas menjelaskan bahwa tokoh "Ia" mempercayai tidak ada manusia yang bisa menangkapnya dan membunuhnya dan hanya malaikat maut yang dapat mencabut nyawanya itupun atas seizin Tuhan Yang Maha Esa.

Nilai pendidikan karakter religius lain dalam cerpen "GoKill!" ditunjukkan dalam kutipan berikut:

"Mengapa tidak ibu lakukan sendiri saja?" Wajah 99 tahun yang menampakkan kepribadian keras itu tersenyum tipis. "kamu tahu aturannya bukan? Dalam agamaku bunuh diri itu dosa." Kukira tidak ada agama yang membenarkan bunuh diri karena putus asa (h.114)

Kutipan di atas menjelaskan bahwa tokoh perempuan tua ingin bunuh diri melalui tangan orang lain karena mempercayai bahwa dalam agama bunuh diri itu dosa dan merupakan tindakan yang tidak terpuji, serta tidak ada satu pun agama yang membenarkan bunuh diri karena putus asa, meskipun pada akhirnya perempuan itu yang membunuh tokoh "Ia".

Nilai karakter religius terakhir yang terkandung dalam cerpen "GoKill” ditunjukkan dalam kutipan di bawah ini:

"Kamu memilih waktu yang tepat, Nak, pada jam seperti ini, selalu sunyi di sini," katanya lagi, "Lakukanlah segera, karena setelah sholat Jumat, para perawat laki-laki akan kembali. Para perawat perempuan juga antre shalat di musholla yang sempit. Ini zaman orang rajin sekali sembahyang". (h.114)

Kutipan di atas menggambarkan bahwa perawat lakilaki dan perempuan menjalankan perintah agama dan sebagai bentuk ketakwaan seorang muslim terhadap agamanya dengan melaksanakan salat Jumat dan perawat perempuan juga menunggu untuk mengantre salat di mushola. Tokoh perempuan tua itu merasa pada zaman ini orang rajin sekali melakukan sembahyang terlihat 
dari bagaimana ia memperhatikan perawat di rumah jompo yang melaksanakan salat Jumat. Hal tersebut mereka lakukan karena memiliki kewajiban untuk melaksanakan ibadah dalam agamanya.

Cerpen lain yang menggandung nilai pendidikan karakter religius terdapat pada cerpen yang berjudul "Budak Cinta". Ditunjukkan dalam kutipan berikut.

Ia menoleh ke arah suaminya, yang sedang membacakan ayatayat kitab suci kepada anaknya sebelum tidur. (h.122)

Nilai pendidikan karakter religius terdapat pada tindakan tokoh "suami" yang ditunjukkan oleh kebiasaannya membacakan ayat kitab suci kepada anaknya sebelum tidur. Tokoh suami juga mengajarkan kebiasaan baik kepada anaknya untuk selalu membaca ayat suci meskipun hanya mendengarkannya.

Nilai pendidikan karakter religius satu hal yang harus dimiliki atau ditanamkan dalam diri perserta didik. Di dalam pembelajaran untuk tetap taat dan mampu menjalankan perintah agama sekaligus menanamkan nilai religius pada perserta didik, guru dapat membimbing perserta didik sebelum memulai pembelajaran untuk membaca surat-surat pendek lalu dilanjut dengan berdoa, setelah selesai pembelajaran ditutup kembali dengan doa sebagai upaya mengucapkan rasa syukur karena dapat menuntut ilmu dengan baik dan tanpa hambatan.

\section{Nilai Nasionalis}

Cerpen yang mengandung nilai pendidikan karakter nasionalis adalah cerpen "Jakarta City Tour". Kutipan yang menunjukkan adanya nilai pendidikan karakter nasionalis ditunjukkan pada kutipan berikut.

"Tidak seorangpun boleh membawa milik pribadi. Sekarang milik pribadi tidak ada, semua disita oleh negara! Makanya jangan sok jadi turis! Sok mau menikmati penderitaan orang lain!”. (h.4)

Dari kutipan tersebut digambarkan bahwa tokoh "Ia" atau pramugari dalam pesawat memiliki perilaku yang cinta pada tanah airnya. Hal ini ditunjukkan dengan kepeduliannya terhadap negara melebihi dirinya sendiri, karena ia berkata tidak boleh ada seorang 
pun yang membawa milik pribadi yang didapatkan dari negara lain karena dirampas oleh turis.

Nilai pendidikan karakter nasionalis lain dalam cerpen "Transit" ditunjukkan dalam kutipan berikut.

Lagipula mereka yang menggenggam kepercayaan lama, tidak membenarkan diri mereka sendiri untuk meninggalkan kampung leluhurnya. (h.33)

Kutipan di atas menjelaskan bahwa tokoh "Ia" memiliki nilai pendidikan karakter nasionalis, sebab tokoh ia mempercayai bahwa mereka (manusia) memiliki rasa kesetiaan dan cinta tahan air untuk tetap tinggal di kampung halaman dan tidak pernah meninggalkan kampung leluhur bagaimanapun keadaannya.

Cerpen lain yang menggandung nilai pendidikan karakter nasionalis terdapat pada cerpen yang berjudul "Setan Becak" yang ditunjukkan dalam kutipan berikut.

"Bapaknya Titun pe-ka-i," kudengar kalimat seperti itu. Kami anak-anak kecil berkerumun, menyaksikan para pemuda dilatih oleh tentara, untuk berbaris dan siap terjun ke suatu pertempuran, meskipun hanya bersenjatakan sebatang bambu. Dari kejauhan kami saksikan di berbagai tanah lapang, para pemuda itu merayap sambal bertiarap, sembari membayangkan peluru berdesing-desing di atas kepala mereka. Dalam terim matahari, mereka harus membayangkan malam yang gelap gulita di dalam hutan, tempat langkah satu mengikuti langkah lain dengan kewaspadaan yang sangat tinggi. (h.97)

Dari kutipan di atas dijelaskan bahwa tokoh "pemuda" dalam cerpen tersebut memiliki sikap nasionalis yang tinggi dengan menunjukkan kesetiaan dan penghargaan terhadap budaya yang melekat di masyarakat. Selain itu, juga dengan melestarikan budaya leluhur ketika berperang menggunakan senjata sebatang bambu. Tokoh pemuda tersebut berlatih dengan tentara untuk terjun ke suatu pertempuran untuk melidungi masyarakat.

Nasionalisme merupakan sikap yang harus ditanamkan dalam diri peserta didik agar menjadi manusia yang menunjukkan 
kesetiaan, kepedulian terhadap bahasa, budaya, dan bangsa. Dalam pembelajaran bahasa Indonesia di sekolah pendidik dapat menanamkan semangat nasionalisme dengan berkomunikasi menggunakan bahasa Indonesia yang baik dan benar dalam proses pembelajaran maupun ketika sedang berdiskusi, dengan begitu peserta didik dengan mudah mencintai bahkan melestarikan bahasa Indonesia. Lingkungan sekolah diharapkan mampu mendukung untuk menanamkan nilai pendidikan karaker nasionalis dengan melaksanakan upacara setiap hari senin sebagai bentuk penghormatan terhadap bangsa Indonesia dan pahlawan yang sudah berjuang.

\section{Nilai Integritas}

Cerpen yang mengandung nilai pendidikan karakter integritas adalah cerpen yang berjudul "Sepatu Kulit Ular". Hal yang menyatakan nilai pendidikan karakter integritas terdapat dalam kutipan berikut.

Aku hanya bisa menundukkan kepala dan melirik ke bawah ke arah belakangku, karena aku sedang berbicara dengan seseorang yang takbisa ditinggalkan sedetikpun meski hanya untuk menoleh sesaat, dan saat itulah kulihat sepatu kulit ular berwarna merah itu. (h.14)

Kutipan di atas menggambarkan bahwa tokoh "aku" memiliki perilaku keteladanan dan kesantunan dengan menjunjung tinggi nilai moral karena ketika ia sedang berbicara dengan orang lain, ia tidak memalingkan pandangannya sedikit pun karena menghargai lawan bicaranya.

Cerpen lain yang mengandung nilai pendidikan karakter integritas adalah cerpen "Transit" yang ditunjukkan pada kutipan berikut.

Terlintas terbayang olehnya wajah-wajah kepada siapa ia telah bersumpah setia. Sumpah yang telah berkali-kali dilanggarnya, tetapi wajah-wajah itu tetap saja mengingatkan betapa ia seharusnya memang setia. (h.29) 
Tokoh "Ia" memiliki perilaku untuk menjadi dirinya yang dapat dipercaya dalam tindakan dan perkataan, karena tetap tinggal dan tidak bertemu dengan wanita yang ingin menemuinya. Tokoh "Ia" ingat dengan sumpah setia yang pernah dia ucapkan meskipun pernah dilanggarnya, tetapi ia tidak ingin mengulanginya.

Cerpen selanjutnya yang mengandung nilai pendidikan karakter integritas adalah cerpen yang berjudul "Gubrak!". Hal yang menunjukkan nilai karakter integritas terdapat dalam kutipan berikut:

"Tetapi saya tidak bisa memaafkan diri saya sendiri jika saya membuat bapak dan ibu di rumah ini, yang sudah saya anggap sebagai orang tua saya sendiri, juga akan jatuh pingsan tak sadarkan diri”. (h.37)

Tokoh "Saya" (perempuan) memiliki nilai kemanusiaan dan menjunjung nilai moral dengan bersikap santun kepada ibu dan bapak. Tokoh tersebut tidak akan memaafkan dirinya sendiri jika membuat bapak dan ibunya tak sadarkan diri karena melihat kecantikannya.

Cerpen selanjutnya yang menggandung nilai karakter integritas adalah cerpen yang berjudul "Istana Tembok Bolong" yang terdapat dalam kutipan berikut:

"Tapi aku tidak akan menambah dosa-dosaku yang sudah bertumpuk ini dengan merusak jiwa anak-anak". (h.86)

Tokoh "Mbak Tum" menjunjung nilai-nilai kemanusiaan dan moral dengan tidak menuruti keinginan anak laki-laki tersebut karena ia takut merusak jiwa anak-anak. Jika ia memenuhi keinginan anak laki-laki itu, ia dapat merusak jiwanya hingga dewasa nanti.

Nilai pendidikan karakter integritas selanjutnya terdapat pada cerpen "Setan Becak" yang terdapat pada kutipan berikut:

"Tidak baik membunuh burung," kata kakak-kakak perempuan, "carilah sasaran benda-benda mati" (h.93)

Tokoh "kakak perempuan" memiliki sikap keteladanan dan menjunjung nilai moral dengan mepercayai bahwa membunuh mahluk hidup lainnya merupakan tindakan yang tidak terpuji. 
Terlihat dari bagaimana ia menasihati adiknya untuk mencari benda-benda mati untuk menjadi sasaran ketapel.

Nilai pendidikan karakter integritas lain yang terdapat pada cerpen "Setan Becak" ditunjukkan pada kutipan berikut:

Cerita tentang sepasang tangan berdarah yang membawa becak itu masih terus ada. Banyak orang seperti mendapat pengalaman yang sama. Ketika mau membayar, yang menerima adalah tangan bermandi darah tanpa tubuh, tanpa kaki, dan tanpa kepala. Kami, anak-anak yang gagah perkasa, tidaklah gampang percaya. (h.98)

Tokoh "kami" atau anak laki-laki memiliki perilaku yang cinta pada kebenaran dengan tidak mempercayai rumor yang dibicarakan masyarakat mengenai sepasang tangan berdarah yang membawa becak, sehingga menyebabkan penumpangnya pingsan ketika mau membayar.

Di dalam proses pembelajaran guru mampu menerapkan nilai karakter integritas dengan meminta peserta didik mengerjakan tugas yang diberikan sesuai dengan kemampuannya tanpa melihat hasil tugas temannya. Dengan begitu guru secara tidak langsung telah menanamkan nilai kejujuran pada diri perserta didik, karena manusia yang baik adalah yang selalu berkata jujur, dapat dipercaya dan sesuai dengan tindakan yang dilakukan.

\section{Nilai Mandiri}

Cerpen yang mengandung nilai Pendidikan karakter mandiri adalah cerpen yang berjudul "Sepatu Kulit Ular" yang ditunjukkan dalam kutipan berikut.

Tapi aku rela dibelit sepasang kaki yang mengenakan sepatu kulit ular warna merah itu. Jika aku harus mati, biarlah aku mati dalam kenikmatan tertinggi. (h.13)

Tokoh "aku” menjadi sosok yang berani karena rela dibelit sepasang kaki yang mengenakan sepatu kulit ular berwarna merah, meskipun ia harus mati. Tokoh "aku" memiliki sikap berani bertanggungjawab menenai keputusan yang telah ia buat. 
Cerpen yang mengandung nilai pendidikan karakter mandiri adalah "Segawon". Kisah seorang pengemis di Kota Paris bersama anjingnya yang besar, gemuk, dan malas. Dia mengemis karena negara tidak memberinya kesempatan untuk berkerja. Hal yang mengandung nilai Pendidikan karakter mandiri ditunjukkan dalam kutipan berikut:

"Saya mengemis bukan karena saya pengemis," kata mereka, "tetapi negara tidak memberi saya kesempatan berkerja. Maka saya pun menganggur, tetapi saya harus tetap makan. Masalahnya, saya hari ini belum makan. Bagaimana sikap anda? Bagaimana kebijakan politik anda?" (h.18)

Tokoh "saya" atau pengemis memiliki karakter kerja keras dan terus berusaha untuk bertahan hidup karena ia tidak berkerja. Tokoh "saya" terus berusaha untuk mencari makan meskipun dengan mengemis karena ia hanya seorang pengangguran.

Selanjutnya cerpen yang mengandung nilai pendidikan karakter mandiri adalah cerpen yang berjudul "Transit". Seperti dalam kutipan di bawah ini:

Lagi pula air apakah kiranya yang akan digunakan untuk mencuci, jika untuk minum pun manusia harus turun dari kampung di atas gunung untuk mengantri. (h.33)

Tokoh ia dalam cerpen tersebut menggambarkan ketika seseorang (manusia) meninginkan sesuatu tentu harus berusaha keras tanpa mengandalkan orang lain. Seperti dalam kutipan di atas bahwa untuk mencuci atau minum pun manusia harus berusaha turun dari gunung untuk mengantri air.

Cerpen yang berjudul "Pulang Berpulang" juga mengandung nilai pendidikan karakter mandiri ditunjukkan dalam kutipan berikut:

"Setiap tahun larangannya semakin keras, tetapi kami tetap datang jua dengan sepedamotor kami masing-masing, berselancar di atas gelombang samudera sepedamotor, dan memang dalam dua tahun berturut-turut, kakakku kedua dan ketiga menyusul kakak pertama, tewas sebagai pemudik bersepedamotor." Apakah itu harus berarti aku akan dan pasti mati jika melakukan pemudikan 
dengan mengendarai sepedamotor? Jika tidak pasti, mengapa kami harus bersikap seolah-olah hal itu pasti? Jika pasti, kematian macam apapun, bukankah mustahil dihindari? (h.67)

Tokoh "kami" atau kakak sukab memiliki sikap yang tidak bergantung pada orang lain dan pemberani, karena meskipun sudah dilarang oleh kedua orangtuanya mereka tetap berusaha merealisasikan harapannya untuk merayakan hari raya di kampung halaman bersama keluarga, hingga pada akhirnya mereka tewas dalam perjalanan menuju kampung halaman.

Cerpen selanjutnya yang mengandung nilai pendidikan karakter mandiri adalah cerpen yang berjudul "Istana Tembok Bolong" yang ditunjukkan dalam kutipan berikut.

Kakinya melangkah dari rel ke rel. banyak sekali rel di dalam stasiun, pikirnya, untung langkah kakinya bias mencakup lebar rel $i t u$, meski sandal jepitnya yang kecil kadang-kadang lepas, dan ia mesti berhenti sejenak untuk memakainya kembali. (h.79)

Kutipan tersebut menjelaskan bahwa tokoh "anak laki-laki" memiliki perilaku mandiri dengan selalu berusaha dan pantang menyerah untuk mencapai apa yang diingikannya, karena anak lakilaki tersebut ingin mencari seorang wanita bernama Mbak Tum di wilayah persilangan kererta api yang menjelma seperti istana tembok bolong, sebab keinginannya mencari Mbak Tum sangat kuat.

Nilai Pendidikan karakter mandiri dalam cerpen "Istana Tembok Bolong" ditunjukkan dalam kutipan berikut ini:

"Kamu membawa uang berapa?"

"Lima puluh."

"Lima puluh? Ambil punya siapa?"

"Itu uangku."

"Uangmu? Kamu berjualan?

"Tidak. Aku menabung"

"Hhhh...." (h.85)

Tokoh "anak laki-laki "memiliki nilai karakter mandiri sebab untuk mendapatkan apa yang diinginkannya ia harus menabung 
terlebih dahulu, menyisihkan uang jajannya hingga akhirnya uangnya terkumpul sebesar lima puluh ribu dan ia bisa bertemu dengan Mbak Tum.

Nilai pendidikan karakter mandiri selanjutnya yang terdapat pada cerpen "Istana Tembok Bolong" ditunjukkan dalam kutipan berikut:

Ia menyalakan batang koreknya yang pertama. Langsung mati tertiup angin.

"Satu ..." kata perempuan itu sambil menghembuskan asap rokoknya ke atas.

Ia menyalakannya lagi, kali ini berusaha melindungi dengan tangan. Tetap mati.

"Dua ..." (h.88)

Dari kutipan di atas dijelaskan bahwa tokoh "ia" atau anak laki-laki terus berusaha untuk melihat apa yang diinginkannya dengan menyalakan korek api. Korek api tersebut terus mati karena tertiup angin dan ia berusaha menutupi korek tersebut menggunakan tangannya, meskipun pada akhirnya sampai korek terakhir ia tetap tidak bisa mendapatkan apa yang diinginkannya.

Cerpen terakhir yang mengandung nilai pendidikan karakter adalah cerpen yang berjudul "Setan Banteng" yang ditunjukkan dalam kutipan berikut:

"Siapa yang berani?" pemimpin rombongan itu bertanya, anakanak kelas VI sekolah dasar itu hanya saling memandang, bahkan ada yang mundur seperti ada sesuatu yang mengancamnya, tetapi ada yang menjawab tantangan itu. "Aku!" (h. 133)

Tokoh "aku" memiliki nilai karakter mandiri karena ia adalah anak yang pemberani. Digambarkan dengan jelas ketika siswa lain hanya saling memandang tokoh "aku" tetap menjawab tantangan itu dengan lantang.

Di dalam pembelajaran guru dapat menanamkan nilai mandiri dengan memberikan materi ajar sebelum memulai pembelajaran agar perserta didik dapat memahaminya sebelum guru menjelaskan. 
Dengan begitu, diharapkan perserta didik mampu menjadi pribadi yang bertanggungjawab, berani, dan pembelajar.

\section{Nilai Gotong Royong}

Cerpen berjudul "Jakarta City Tour" terdapat nilai pendidikan karakter gotong royong yang ditunjukkan dalam kutipan di bawah ini.

Selama kurang dari lima menit dengan panik mereka mencoba memecahkan jendela, menjebol pintu, maupun kaca depan. Namun semua itu sia-sia. (h.7)

Dari kutipan di atas dijelaskan bahwa tokoh "turis" di dalam bus berusaha dan saling berkerja sama untuk memecahkan jendela bahkan menjebol pintu ketika melihat ada timer sebuah bom yang terus berjalan di dalam bus.

Selanjutnya cerpen yang mengandung nilai pendidikan karakter gotong-royong adalah "Segawon" yang ditunjukkan dalam kutipan berikut:

Aku mungkin tidak mempunyai kehormatan, tetapi aku ternyata memiliki belas kasihan. (h.22)

Tokoh “ia” memiliki rasa empati kepada perkerja McDonald's yang memiliki perkerjaan lebih layak darinya dengan menuruti keinginan pekerja tersebut untuk meninggalkan tempatnya karena penampilannya yang kumuh dan para pembeli merasa jijik dengan bau dan tampangnya. Para perkerja pun takut pelanggannya tidak datang lagi karena pengemis tersebut selalu ada di sini.

Nilai Pendidikan karakter gotong-royong lain dalam cerpen "Segawon" yaitu terdapat dalam kutipan berikut:

Begitulah hidupku dari tahun ke tahun sampai krisis ekonomi membuat hidup semakin susah. Setiap hari orang-orang yang hanya kulihat sepatunya melangkah di depanku bergunjing tentang makin sulitnya mencari makan, dan tak sedikit yang menyatakan betapa menyebalkannya bahwa penghasilan mereka yang sedikit itu masih harus dipotong oleh negara untuk memberi makan orang miskin. (h.23) 
Kutipan di atas menjelaskan bahwa meskipun tokoh "mereka" tidak pernah secara langsung memberikan pertolongan atau bantuan kepada masyarakat kecil, tanpa disadari oleh penghasilan berkerja mereka selama ini dipotong oleh negara untuk membantu memberi makan masyarakat kecil.

Nilai pendidikan karakter gotong-royong lain dalam cerpen "Segawon" yaitu terdapat dalam kutipan berikut:

Di sebelahnya kulihat seekor anjing, yang besar, tua, dan tampak bodoh, yang pastilah miliknya, yang segera kubawa karena memang tak seorang pun di dunia ini akan peduli kepada seekor anjing milik gelandangan yang sudah mati. (h.24)

Tokoh "aku" memiliki rasa empati dan tolong menolong terhadap sesama mahluk hidup pada seekor anjing yang ditinggal mati pemiliknya, ia membawa anjing itu pergi bersamanya dan selalu berusaha memberi makan anjing tersebut.

Cerpen lain yang mengandung nilai karakter gotong-royong adalah cerpen berjudul "Gubrak!” dalam kutipan berikut.

"Jangan ambil wajahnya ya! Jangan! Nanti pingsan semua kita di sini!"

Sejak awal juru kamera kepolisian itu pun telah mendapat peringatan dari rekannya di bawah.

"Awas! Ambil dari jauh saja! Kita hanya perlu mengetahui arah perjalanannya! Awas! Kalau melihat wajahnya kamu bisa jatuh pingsan melayang ke bawah!"

“Oke! Oke! Wajah tidak diambil! Copy!” (h.40)

Dari kutipan di atas dijelaskan bahwa tokoh juru kamera dan polisi memiliki semangat kerja sama dengan saling membantu menyelesaikan masalah secara bersama-sama dengan komunikasi yang baik agar tidak terjadi kesalahpahaman, serta memiliki tanggungjawab dan mematuhi apa yang diperintahkan oleh rekannya.

Cerpen lain yang menggandung nilai pendidikan karakter gotong-royongterdapat pada cerpen yang berjudul "Pulang Berpulang" ditunjukkan dalam kutipan berikut: 
"Masalahnya, Sukab, masalahnya, ketiga kakak laki-lakimu itu tewas satu persatu, ya, tiap tahun satu-satu, dalam perjalanan pulang demi Hari Raya. Satu persatu mereka meninggalkan dunia ini di atas sepeda motornya, langsung terbang menuju alam baka tanpa ditunda. Kamu pun mengetahui itu Sukab! Mengerti dan ikut merasakannya. (h.64)

Kutipan di atas menjelaskan bahwa tokoh "Bapak" memiliki rasa empati dan kekeluargaan dengan cara mengingatkan anaknya "Sukab" untuk tidak pulang ke kampung halaman menggunakan sepeda motor karena takut terjadi sesuatu di jalan, sebab setiap tahun satu-persatu kakaknya meninggal dunia dalam perjalanan pulang demi merayakan hari raya di kampung halaman.

Cerpen selanjutnya yang mengandung nilai pendidikan karakter gotong royong terdapat pada cerpen berjudul "Setan Becak" yang ditunjukkan dalam kutipan berikut.

"Orang-orang yang berdatangan karena mendengar jeritan perempuan itu tergeletak pingsan. Mereka berdatangan menolongnya. Setelah perempuan itu siuman, mereka dengar cerita tentang sepasang tangan yang bergelimang darah dan darahnya mengalir ke bawah." (h.96)

Dari kutipan di atas digambarkan bahwa tokoh "masyarakat" dalam cerpen tersebut memiliki rasa solidaritas yang tinggi dengan memberi bantuan atau pertolongan kepada perempuan yang pingsan setelah menaiki setan becak.

Cerpen terakhir yang mengandung nilai pendidikan karakter gotong-royong yaitu cerpen yang berjudul "Setan Banteng" ditunjukkan dalam kutipan berikut.

Anak itu sendiri yang tadinya tersungkur, berbalik dan mengusap mata bagaikan baru terbangun dari tidur. Guru, yang tampaknya mengerti belaka permainan semacam ini, mengangkatnya bangun dan merangkul bahunya. (h. 137)

Dalam cerpen tersebut digambarkan bahwa tokoh "guru" memiliki rasa empati dan sikap kerelawanan karena menolong 
muridnya yang jatuh tersungkur setelah bermain setan banteng dengan menangkat dan merangkul bahunya.

Di dalam pembelajaran perserta didik diharapkan mampu memotivasi diri sendiri maupun orang lain. Pendidik mampu menanamkan nilai karakter gotong-royong dalam proses pembelajaran dengan membentuk kelompok diskusi yang sesuai dengan K.13 untuk menyelesaikan tugas yang diperintahkan oleh pendidik. Tanpa disadari siswa memiliki dan sudah menanamkan kerja sama dan memiliki rasa peduli satu sama lain.

\section{PENUTUP}

Berdasarkan hasil penelitian dan analisis data yang dilakukan maka dapat disimpulkan bahwa dalam kumpulan cerpen Transit karya Seno Gumira Ajidarma terdapat nilai pendidikan karakter. Peneliti menemukan 31 nilai pendidikan karakter yang dibedakan menjadi lima kriteria, diantaranya: (1) nilai religius yang ditemukan berjumlah 6 kalimat, (2) nilai nasionalis yang ditemukan berjumlah 3 kalimat, (3) nilai integritas yang ditemukan berjumlah 6 kalimat, (4) nilai mandiri yang ditemukan berjumlah 8 kalimat, (5) nilai gotong-royong yang ditemukan berjumlah 8 kalimat.

Kumpulan cerpen Transit karya Seno Gumira Ajidarma dapat dijadikan bahan ajar pembelajaran Bahasa Indonesia di SMA tentang cerpen yang terdapat di kelas XI semester 1 KD 3.8 yang di dalamnya mengidentifikasi tentang nilai-nilai kehidupan yang terkandung dalam kumpulan cerpen yang dibaca. Kumpulan cerpen Transit karya Seno Gumira Ajidarma menggunakan bahasa yang tidak sulit untuk di pahami, sehingga diharapkan perserta didik mampu menemukan nilai pendidikan karakter di dalamnya sehingga dapat dijadikan gambaran atau acuan untuk diaplikasikan dengan baik di kehidupan sehari-hari. 


\section{DAFTAR PUSTAKA}

Aminudin. (2015). Pengantar Apresiasi Karya Sastra. Bandung: Sinar Baru Algensindo.

Hudhana, Dwi, Windha. (2018). Metode Penelitian Sastra; Teori dan Aplikasi. Yogyakarta: Samudra Biru.

Kemendikbud. (2017, Juli 17). Penguatan Pendidikan Karakter Jadi Pintu Masuk Pembenahan Pendidikan Nasional.

Samani dan Hariyanto. (2017). Konsep dan Model Pendidikan Karakter. Bandung: PT Remaja Rosdakarya.

Salahudin, Anas dan Alkrienchiehie, I. (2013). Pendidikan Karakter (Pendidikan Berbasis Agama dan Budaya Bangsa). Bandung: Pustaka Setia.

Sulaeman, A. \& Ariyana, A. (2018). Pengaruh Penggunaan Model Pembelajaran Examples Non-Examples Terhadap Hasil Belajar Menulis Teks Berita pada Siswa Kelas VII SMPN 14 Kota Tangerang. Silampari Bisa: Jurnal Penelitian Pendidikan Bahasa Indonesia, Daerah, dan Asing, 1(2), 17.

Sutri. (2020). Nilai Sosial Dalam Kumpulan Cerpen Keluarga Owig Karya Adhimas Prasetyo, dkk (Kajian Sosiologi Sastra). IAIN Surakarta: Tabasa: Jurnal Bahasa, Sastra Indonesia, dan Pengajarannya, 1(1).

Wicaksono, Andri. (2014). Menulis Kreatif Sastra dan Beberapa Model Pembelajarannya. Yogyakarta: Penerbit Garudhawaca.

Youpika, Fitra dan Zuchdi D. (2016). Nilai Pendidikan Karakter Cerita Rakyat Suku Pasemah Bengkulu dan Relevansinya Sebagai Materi Pembelajaran Sastra. Program Pasca Sarjana Universitas Negeri Yogyakarta. Tahun VI, Nomor 1, April 2016, hal 50.

Yulianto, Agus, dkk. (2020). Analisis Nilai-Nilai Pendidikan Karakter dalam Novel Rumah Tanpa Jendela Asma Nadia. IAIN Surakarta: Tabasa: Jurnal Bahasa, Sastra Indonesia, dan Pengajarannya, 1(1). 
Widiatmoko, Anggoro, D, dkk. (2020). Pengembangan Kartu Bergambar Tiga Dimensi Sebagai Media Pembelajaran Menulis Teks Berita. IAIN Surakarta: Tabasa: Jurnal Bahasa, Sastra Indonesia, dan Pengajarannya, 1(1). 